岩石鉉物鉖休学会誌

55 巻 2 号, 1966 年

\title{
北海道発足ベントナイト鉱床 (II)
}

Bentonite deposits at Hattari, Hokkaido (II)

\author{
浦島幸 世 (Yukitosi Urasima) \\ 庄谷幸夫 (Yukio Syoya) \\ 須 崎 祐 吉 (Yukichi Suzaki)
}

\section{5. 鉱石}

\section{a. 外観と顕徽鏡的性啠}

坑内外の全露頭の鉣石と母岩の試料加ら，外矰とX線回折の結果を考應して，代表的 陚料をえらび，それらの影微鏡的性質をしらべた。

良質のベントナイトの外観と㩆徽鏡的性質については，その1例（PHd1) がすでに報 告され(浦島，1963)また，第 1 表にも外㓋を列記したので，ここでは一般的性質を略記す る。鉝石は，乾燥前には，たいてい淡黄灰色，あるいは，焱緑灰色で，弱い脂感呈寸る が，乾くと白色に近くなり，光沢に之しく，細粒均質の㠜灰岩の外観を示す。水を子くん で膨潤した鉝石は乾燥すると割目が生じやすい。

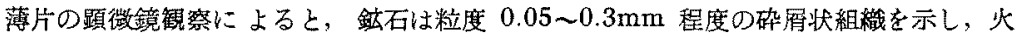
山ガラスと石英が大部分を占め，斜長石がこれにつぎ，少量の黒需母がふくまれている。

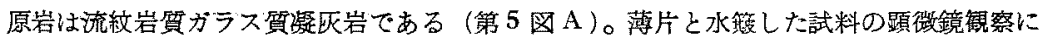
よれば，ガラス片には，おもに沸石と $a$ クリストバル石が生じ，ガラス片の縁边部と基 質がモンモりロナイト化している。乾式研磨面はベンチジン飽和水溶液で斑紋状に青色を 呈し，その部分はないてい凹部，すなわち基䁈部である。

鉣床の西方 (上盤側)，すなわち，C 带には，少量の白色緻密堅硬で光沢の乏しい蛋白 石化岩がおもに，転石となつてみとめられる。わすかに淡紫色を呈する縞目によつてこ まかな葉理がみとめられ，貝殼状にわれる。薄片の篗祭によれば，原岩は径 $0.01 \mathrm{~mm}$ 程 度の火山ガラス・石英，少量の緑色化鉝物加らできている碎屑状組樴をもつ細粒凝灰岩で ある(第 5 図 B)。

鉉床の東方(下盤側)，すなわち A 带には，淡緑厌色凝灰岩が分布しているが，そのうち， 方沸石が多くふくまれているものは，灰白色となつていることが多い。ベントナイトの場 合と同栐の原岩の組織をもつものもあるが，肉眼的，あるいは㩆徽鏡的にやや暗色の斑点 がしばしばみとめられる。その斑点は径 $0.05 \sim 0.2 \mathrm{~mm}$ 程度で，火山ガラス片の集合体 で，ほかに，少量の石英や黒雲母がふくまれている。火山ガラス片の縁辺部と基啠は徽粒 の粘土铰物と方沸石に変つている(第 5 図 C,D)。

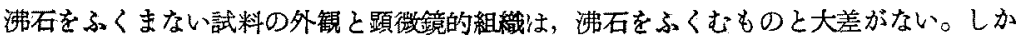
し，前者には，観祭した範围では，火山ガラスの斑紋状組織がいこと，岩石片を多くふ くむものがあること，珪化(石英化)していること，などの傾向があることがあげられる（第 5 図 E)。第 5 図 $\mathbf{F}$ 蛙，緑色と褐色の葉理を示し，石英・斜長石・灿山方ラス・安山岩 


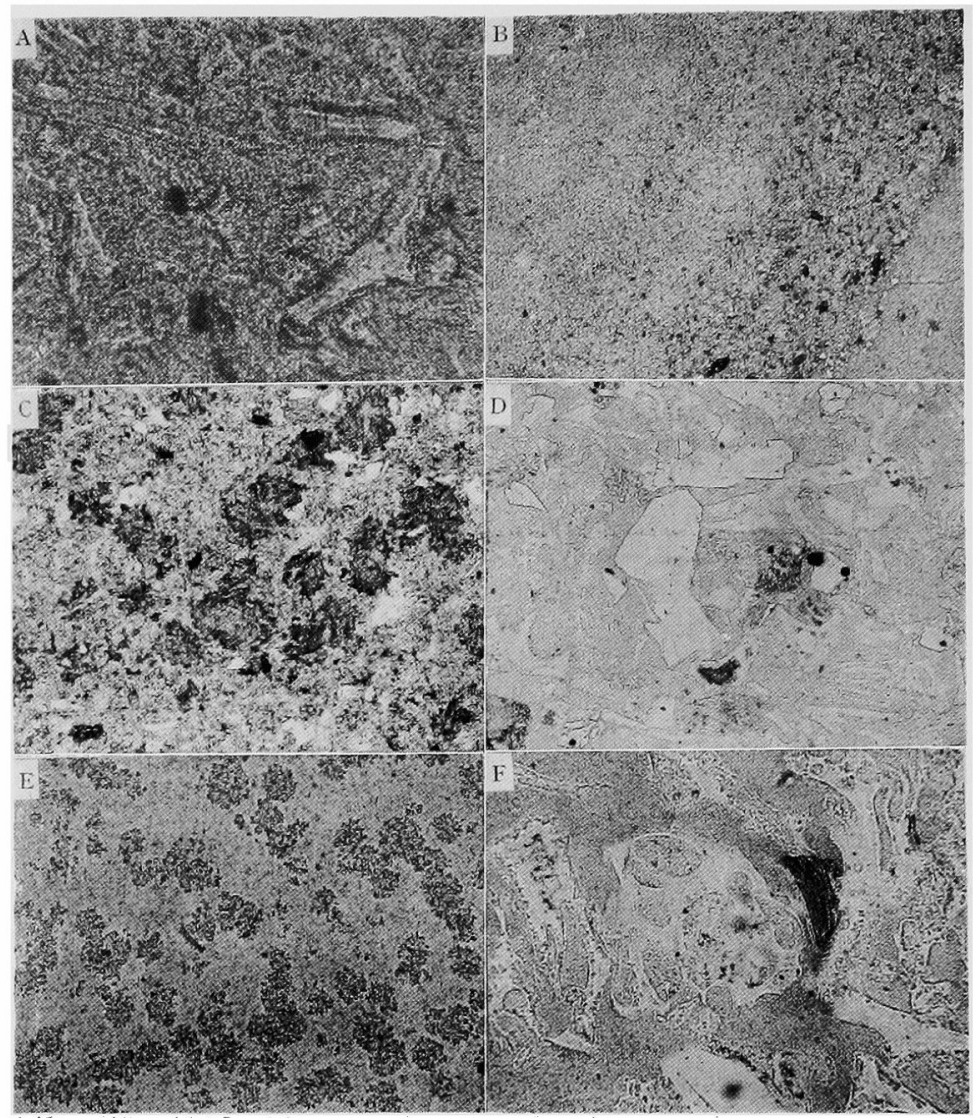

第 5 図鉱石の顕微鏡写真

A. ペントナイト (モンモリロナイト・斜プチロル沸石・ $a$-クリストバル石化凝灰岩

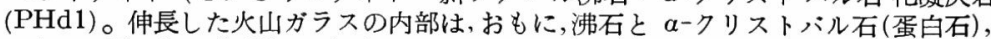
ガラスの縁辺部と基質部は,おもに，モンモリロナイトと $\alpha$-クリストバル石。薄片， 通常光, $125 \times$ 。

B. 蛋白石化凝死岩 (QDA1)。石英や緑色化鉣物の多い粗粒部之微粒火山ガラス片 $(\boldsymbol{a}-$ クリストバル石・蛋白石化）の多い細粒部による葉理。薄片，通常光，27×。

C. モンモリロナイト・方沸石化凝灰岩 (BK4)。火山 ガラスの集合 (扊色斑点), 石英 (白), 変質した黒雲母 (黒の一部)。ガラス片の縁辺部と基質部がモンモリロナイトと 方沸石。薄片, 通帯光, $27 \times$ 。

D. 方沸石 化凝灰岩 (B9)。火山ガラス片集合 (正色斑点), 褐色で变質した黒雲母 (灰色 伸長結晶)。火山ガラス片縁辺部と基質部が方沸石。薄片, 通常光, $50 \times$ 。

E. 珪化凝灰岩 (B14)。石英 (白, 境界明瞭の結晶), 火山ガラス (白), 火山ガラス片 の外带は玉髄質石英化。薄片, 通常光, $27 \times$ 。

F. 水長石 - 石英化凝灰岩 (BGF8)。石英 (中央下の白), 緑色黒 雲母 (扊), 火山カラ スと浮石 (不規則形の白)。火山ガラスの外带は石英化。中央左端では縁辺部に氷長 石 (三角形)。薄片, 通常光, $125 \times$ 。 


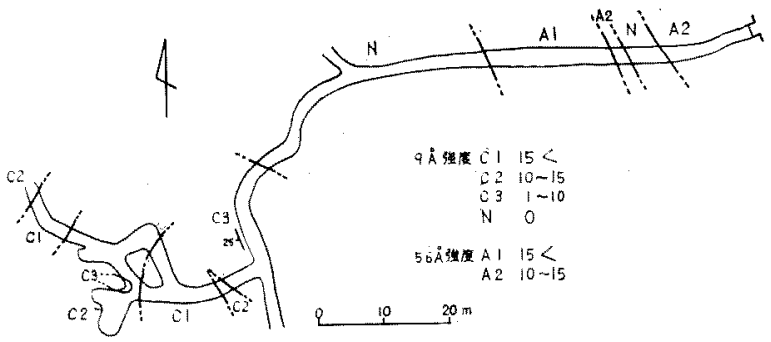

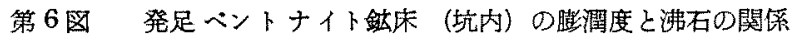

第 4 図々比較。沸石の相対量はX 線回折図のビークの高さ。
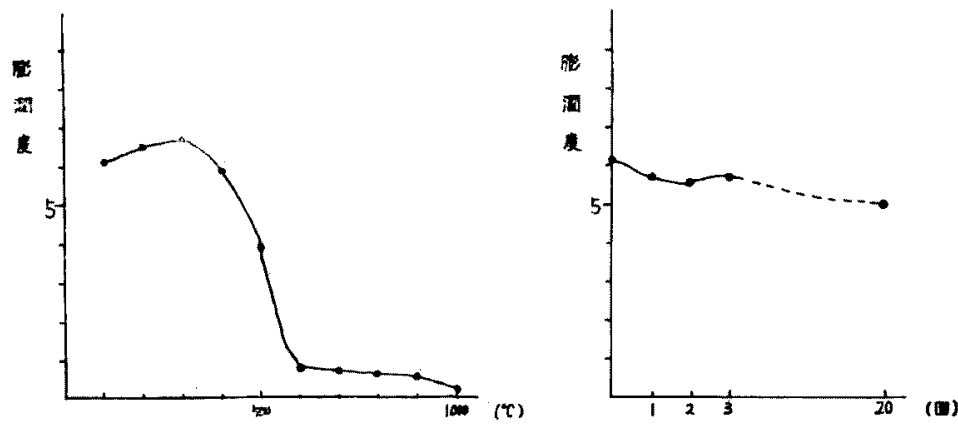

第7図発足ベントナイトの処理による膨潤度変化

左は膨㵎度の大きい試料 (BK 13) の加熱温度と膨潤度の関係。 右は同じ武料の膨琵回数と膨潤度の関係。

片などからできている珪化凝灰岩で，火山ガラス片の外带が石英・氷長石化（径 $0.01 \mathrm{~mm}$ 程度)している例示す。

\section{b. 膨湢性}

ベントナイト銥石は，坑内で水をふくもことがあれば，瞦㶄して，ときには，流動する。 膨潤した鉱石には，乾くと割目が発逹する。試料は水中ですぐ膨潤してとうぶ状になり，

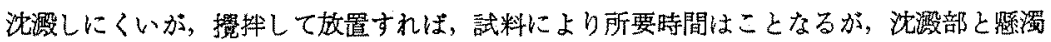
部に分れる。

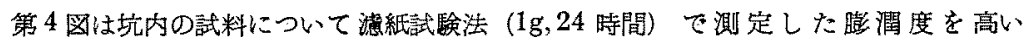
もの加ら鿓に $\mathrm{B}_{\mathbf{1}} \cdot \mathrm{B}_{2} \cdot \mathrm{B}_{3} \cdot \mathrm{B}_{4}$ ，に区分して示したものである。その最高は 6 程度である。

採取試料のうち，もつとも膨潤度が高い試料 (BK13) の膨潤度が加熱によつて低く なることを示したのが，第7図左である。 $450^{\circ} \sim 800^{\circ} \mathrm{C}$ 間の脱水で膨濯性がなくなる例

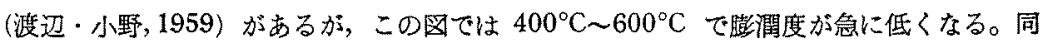
図右は，膨潤回数（水による膨㧚とその後 $100^{\circ} \mathrm{C}$ の恒温槽での乾襙のくりかえしの回数） と膨潤度との関係図で，膨㵎のくりかえしによつて，膨潤しにくくなる。 
第 2 表 発足ベントナイト中の斜ブチロル沸石の X 線回折

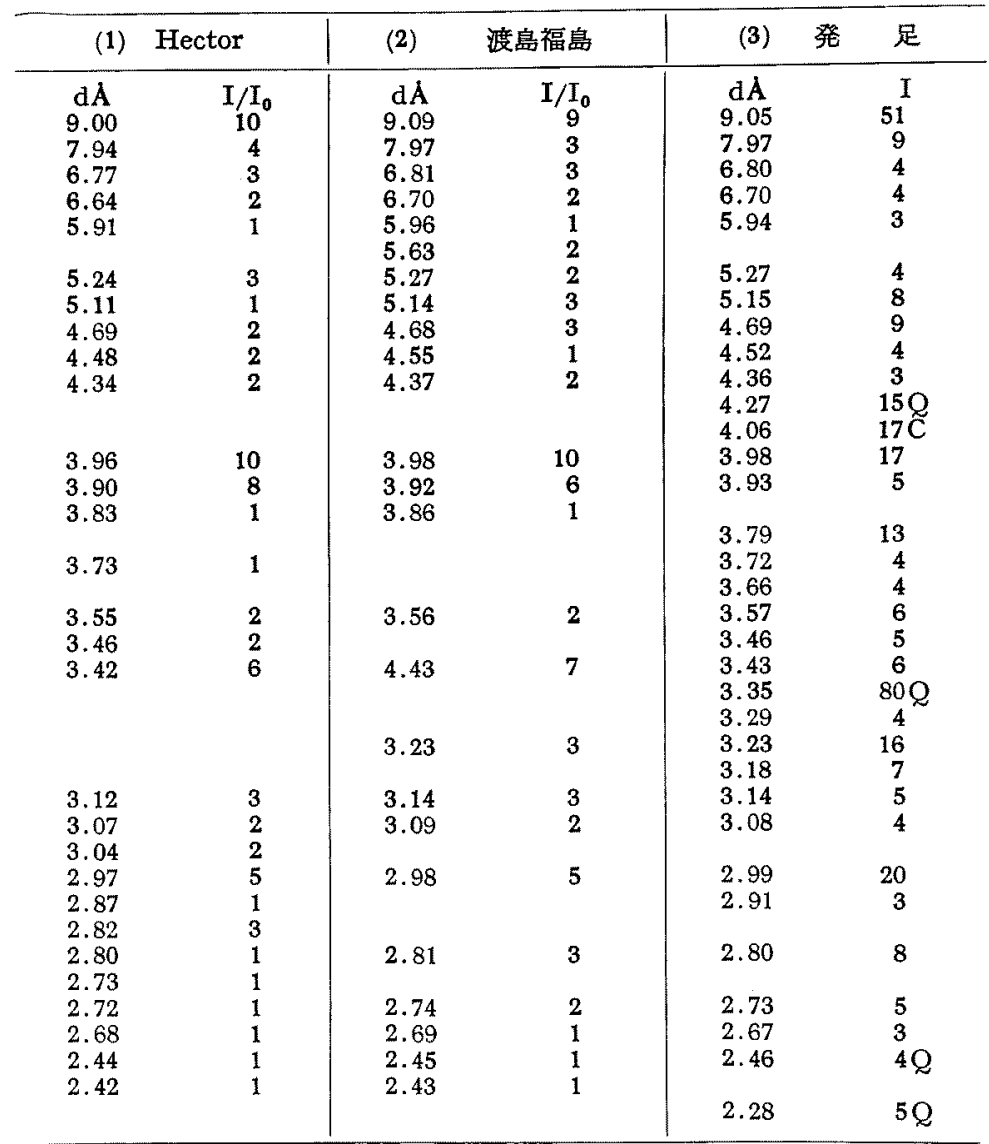

(1) Mumpton (1960)。

(2) 吉村 (1961)。

（3）試料（BK13）の水籍沈湟部分を $60^{\circ} \mathrm{C}$ て乾燥したもの。Q：石英, $\mathrm{C}$ ：a-クリストバル石。Geigerflex ；CuKa/Ni，30KV，15mA， $0.5 \% \min , 16-1-2$ 。

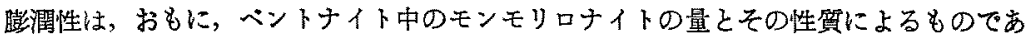
るが，X楾粉末回折図の 14〜15A（001）のビークの高さよりも，そのビークの複雑な形 に関係している。すなわち，そのビークの形のうち，巾が狭くするどい形のものをN型， 正三角形状で巾が広いものを B，ゆるやかな丘状のものをD とすると，第 1 表が示すよ うに，膨溜度が高い試料の大部分のビークはB 型である。モンモリロナイトの量が多く， また，その (001) の構造が不安定な場合に，ベントナイトの膨閏度が高くなることを示 している。 
坑内の試料の膨㵎度と浙石との関係は，第6図と第 1 表に示される。この罒によれば， 膨潤度は沸石の量の多少にあまり関係しない。

C 帶の大部分の湖潤度は 3.10〜6.08である。ただし，その带にふくまれ，通称“ガメ” とよばれる不規則塊状で白色硬質部分の膨潤度は0.99〜2.63である。また，A 带では， その值が 1.17〜 1.52 で, 無沸石带, すなわち, N 带では, 1.34〜2.22 となつている。

\section{c. $\mathrm{X}$ 線的性咓}

発足ペントナイトの不分䍊試料 (PHd1) のX線回折結果，および，同じ試料を水中 で㩭䢁すると，モンモりロナィトと ロル沸石・aークリストパル石・石英などを主とする沈澱部に，たやすく分かれることは， すでに，報告した（浦島，1963）。

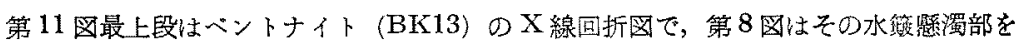
$60^{\circ} \mathrm{C}$ で乾喿してえた䧕料のそれを示している。主成分鉝物のモンモりロナイトは後者に

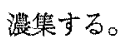

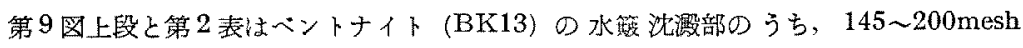
のものの X 線回折結果である。その結果汢, 此較のために同衰に記した Hector (Mumpton, 1960) と渡島, 福島（吉村, 1961） の斜プチロル沸石のデータとよく一致して いる。モルデン沸石の 13〜14A のビークはみとめら机な。また石英と 儿石が混在している。境内の鉱石にかぎらず，ベントナイト鉱床中，および，その南西側 (上盤側) の凝死岩にふくまれる主成分鉣物は試料 PHd1 や BK13 の場合と同様である。 比較のために，羽㹸の沸石岩（服部幸雄談話によると白亜紀層）について，同様の奏験 を行なつた結果によると，これは石英粒に之しい流紋岩質疑灰岩で，主要鉉物組成はモン

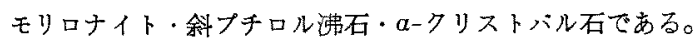

ベントナイト鉝床からはなれて，その北東側（下瞥側）に分布する凝灰岩の不分離試料 (D2) のX線回折の結果洅第 3 素の通りで，この種の凝灰岩は方沸石と石英を主成分と することがわかる。このち沸石は東北地方の凝灰岩中のち沸石のデータとわずかにことな

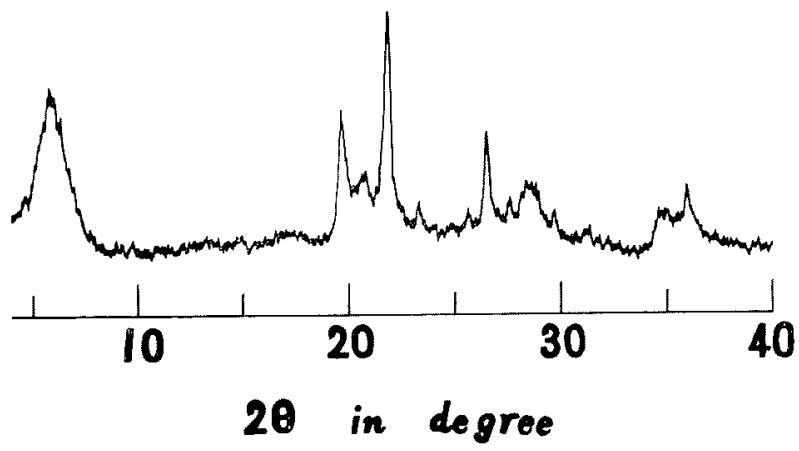

第8図発足ベントナイト (PHdl) の水簯篦濁部の X 線回折図 モンモリロナイトと $a$ クリストバル石。Cuka, $30 \mathrm{KV}, 10 \mathrm{~mA}$ $2^{\circ} / \min$., 16-1-2. 


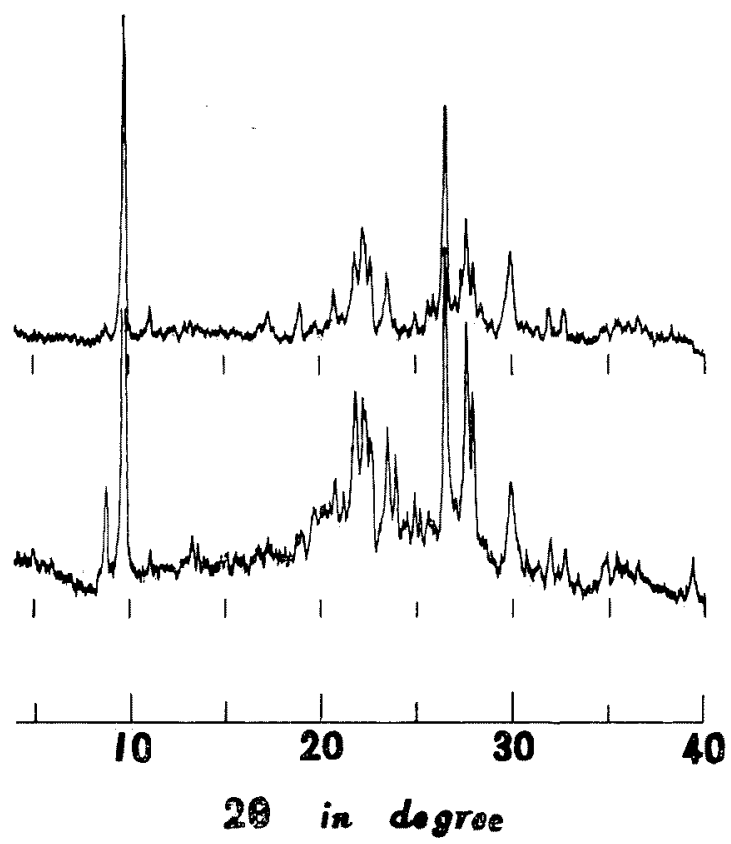

第9四発足ベントナイト(BK13) の水籍沈搌部のX線回折図 斜プチロル沸石， $a$ ークリストハル石，および石英。上は塩酸妈理前 のもの。Cuka, 25KV, $10 \mathrm{~mA}, 2^{\circ} / \mathrm{min} ., 8-1-2$ 。下は塩酸処理 (1 時間) 役の\&の $30 \mathrm{KV}$ その他は同条件。

る点がみとめられるが，McConnell (1952) の方沸石のデータや根空花啖の粗粒玄武岩 晶洞の方沸石についてえた結果とよく一致している。方沸石に類似した構造を持つワイラ カイトでは，(400) のX線反射が $3.42 \AA$ と $3.39 \AA$ の 2 つに分かれ，(200)の反射が より强くあらわれる(Coombs, 1955)。

斜ブチロル沸石化岩の中に挾在する蛋白石化岩 (QDA1) のX 線回折図は第 10 図で, aークリストバル石・蛋白石と少量の石英のビークがみとめられる。薄片の観察によれぱ， この石英の大部分は原岩中の砕片である。

薄片観察とX線回折によれば，第1表に示すように，セラドナイトと推定される緑色 粘土鉝物をふくむ緑色㠜压岩がある。それらは，たいていヘンンナイト化していないが， 录色鉱物と沸石，あるいはモンモリロナイトとの関係については，な扮検討を要する。

d. 加熱変化と示差熱曲線

ヘントナイト鉱石の賠潤度の加熱変化については前に述へたので，ここでは，加熱 $\mathrm{X}$ 線回折結果を記す。すなわち，鉉石試料 $\mathrm{BK} 13$ を乳鉢で粉末とし，100 $\mathrm{C}, 200^{\circ} \mathrm{C}, \cdots$ の各温度に 1 時問加熱し，テシケーター中て 30 分泠却し， $\mathrm{X}$ 線粉末回折图をもとめた (第 11 図)。モンモリロナイトを示す $15 \mathrm{~A}$ のビークは $100^{\circ} \mathrm{C}$ て低くなり，200ㄷ ては 
第 3 表 発足の凝灰岩中の方沸石のX線回折

\begin{tabular}{cc|cc|cc}
\hline \multicolumn{2}{c|}{ (1) McConnell } & \multicolumn{2}{c|}{ (2) 根室 } & 花咲 & \multicolumn{2}{c}{ (3) } & 発 & 足 \\
\hline $\mathrm{dA}$ & $\mathrm{I} / \mathrm{I}_{0}$ & $\mathrm{dA}$ & $\mathrm{I}$ & $\mathrm{dA}$ & $\mathrm{I}$ \\
5.57 & 0.9 & 5.60 & 58 & 5.60 & 46 \\
4.87 & 0.4 & 4.86 & 21 & 4.86 & 9 \\
& & & & 4.27 & $54 \mathrm{Q}$ \\
3.66 & 0.2 & 3.66 & 4 & 3.66 & 4 \\
3.42 & 1.0 & 3.42 & 84 & 3.42 & 75 \\
& & & & 3.35 & scale out $Q$ \\
& & & & 3.30 & 4 \\
2.915 & 0.7 & 2.92 & 49 & 3.23 & $7 \mathrm{~B}$ \\
2.800 & 0.2 & 2.80 & 5 & 2.92 & $4 \mathrm{~B}$ \\
2.690 & 0.3 & 2.69 & 12 & 2.80 & 4 \\
& & & & 2.69 & 8 \\
2.505 & 0.3 & 2.50 & 11 & 2.58 & $5 \mathrm{~B}$ \\
2.430 & 0.2 & 2.42 & 9 & 2.50 & 6 \\
& & & & 2.46 & $14 Q$ \\
\hline
\end{tabular}

(1) McConnell (1952).

(2) Geigerflex; Cuk $\alpha / \mathrm{Ni}, 25 \mathrm{KV}, 5 \mathrm{~mA}, 2^{\circ} / \mathrm{min}, 8-1-2$.

(3) D2, Q : 石英. Geigertlex, Cuk $\alpha / \mathrm{Ni}, 30 \mathrm{KV}, 10 \mathrm{~mA}, 0.5^{\circ} / \mathrm{min}, 16-1-2$.

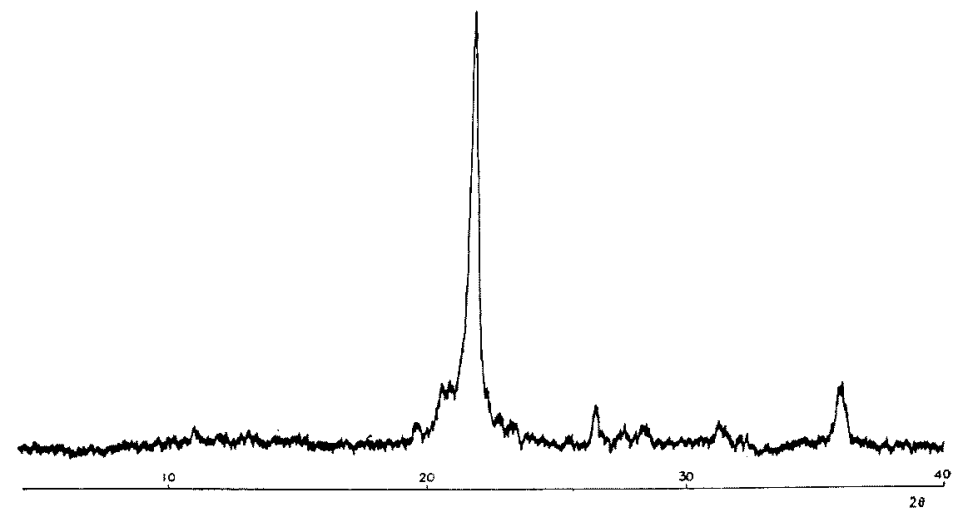

第 10 図発足の蛋白石化岩 (QDA1) のX 線回折図。

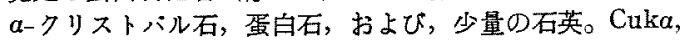
$30 \mathrm{KV}, 10 \mathrm{~mA}, 2^{\circ} / \mathrm{min}, 8-1-2$.

みとめられなくなる。沸石の $9 \AA$ のビークは $800^{\circ} \mathrm{C}$ までみるられるが，900 C では 消失している。試料 PHd1 の水籍沈潣部の埸合には, $700^{\circ} \mathrm{C}$ \& $900^{\circ} \mathrm{C}$ の間は $50^{\circ} \mathrm{C}$ の間隔で実験を行なつたが，850ㄷ 加熱までみとめられる沸石の X 線粉末反射が， $900^{\circ} \mathrm{C}$ ては消失している。比較のために，羽幌の沸石岩の水笻沈激試料を同様の方法で赛

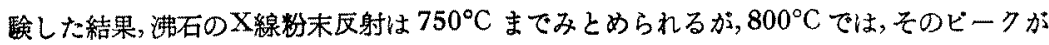
消失している。 


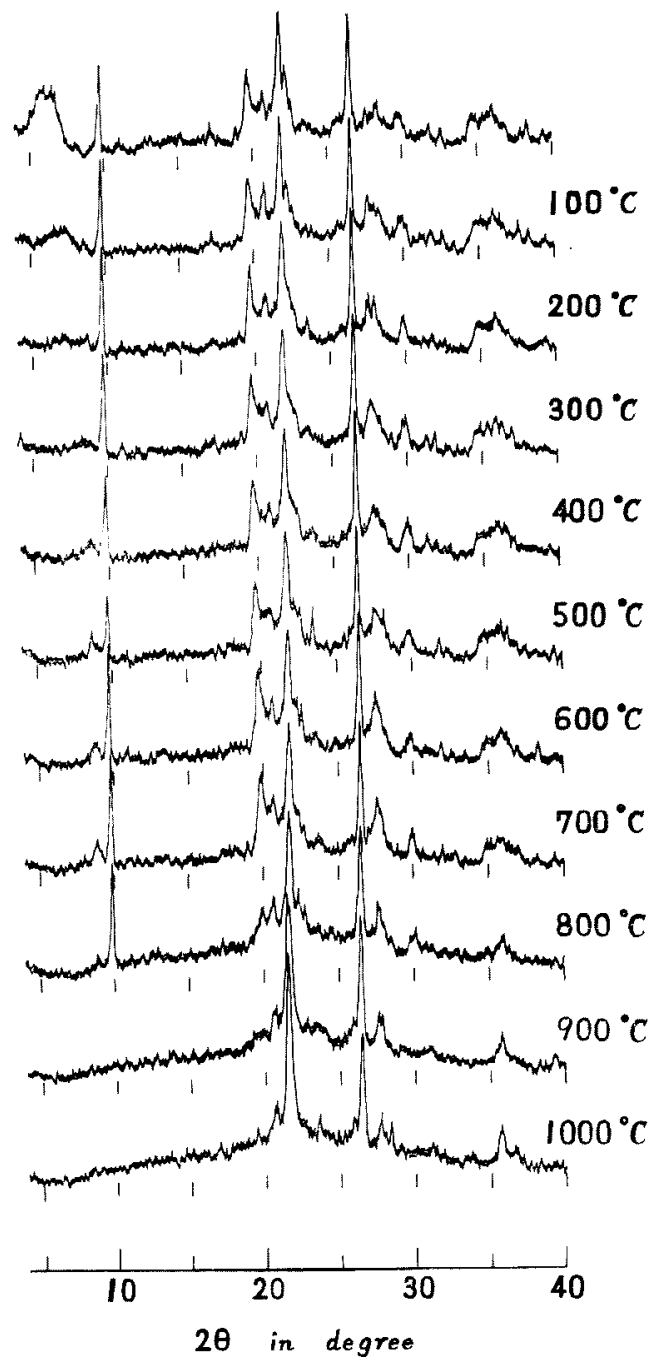

第11図発足ベントナイト (BK13) の加熱X 線回折図

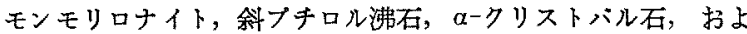
ひ，石英。 $100^{\circ} \mathrm{C} て ゙ 15 \AA$ のビークが崩れ， $200^{\circ} \mathrm{C}$ では消える。 $900^{\circ} \mathrm{C}$ で $9 \mathrm{~A}$ のビークが消える。Cuka, $30 \mathrm{KV}, 10 \mathrm{~mA}, 2 \% \mathrm{~min}$ 8-1-2. 
従来の例によれば，モルデン沸石は斜ブチロル沸石よりも，熱に対してわずかに安定で あることが知られている (Sudo et al., 1963)。したがつて，前記の実医は，発足へント ナイト中の沸石が，德に対しては，斜ブチロル沸石よりもモルデン沸石に近い性質のもの で，羽幌の沸石は斜ブチロル沸石の性筫をもつことを示している。

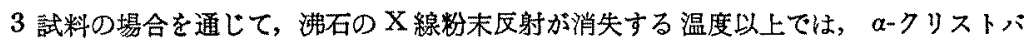
ル石のそれが残り，4A の反射吕鮮明化する傾向がある。

発足ベントナイト鉱石の水筑照濁部の示盖熱曲線はモンモリロナイトの曲線を示してい る(第 12 図)。同沈澱部, および, 鴻之舞の流舫岩晶洞中の試料でX線回折によりモルデン 沸石に同定されるものの示差熱曲線では，いずれも $150^{\circ} \mathrm{C}$ 付近にわずかな吸熱ビークが あるほかには、いちじるしいピークはみとめられない。雨試料の示差熱曲線では, 斜プキ ロル沸石とモルデン沸石は顥著な特徵を示しにくいものと考えられる。

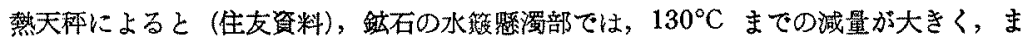
た，600 ${ }^{\circ} \mathrm{C}$ 付近でもそれがみとめられるのに対し，同沈澱部はいちじるしい減量を示さ ず，示差熱曲線の結果と対応している。

\section{e. 溶媒好理}

加熱変化の实験にもちいた試料 (BK13) を $6 \mathrm{~N}-\mathrm{HCl}$ で水蒸気浴上で 1 時間 加熱した あと，蒸溜水で洗い，乾燥したもののX線粉末回折図は，第9园が示すように，沸石の 粉末反射を残している。他方，羽㿠の試料では，塩酸処理によつて沸石の粉末反射が消失 してい。

斜プチロル沸石注塩酸によつて分解しやすく，モルデン沸石は分解しにくいということ が知られている (Sudo et al., 1963).ので, これらの実験結果は発足の沸石はモルデン沸 石の性質に近く，羽幌の沸石は斜プチロル沸石であることを示している。

以上の実験結果をまとめると，発足ベントナイト中の沸石は，常温のX線回折では， 斜ブチロル沸石の結果に一致するが，加熱と塩酸処理によるX線回折では，モルデン沸石 に近い性質を示す。したがつて，この点は将来なお検討を要する問題である。

\section{f. 化学成分}

第 4 表注発足ヘンンナイト関係の化学分析值を示す。1 と 2 は镀石であるが，3 は試 料 PHd1 の水䑴沈澱部で, 報告されている斜ブチロル沸石の分析值 (Mason and

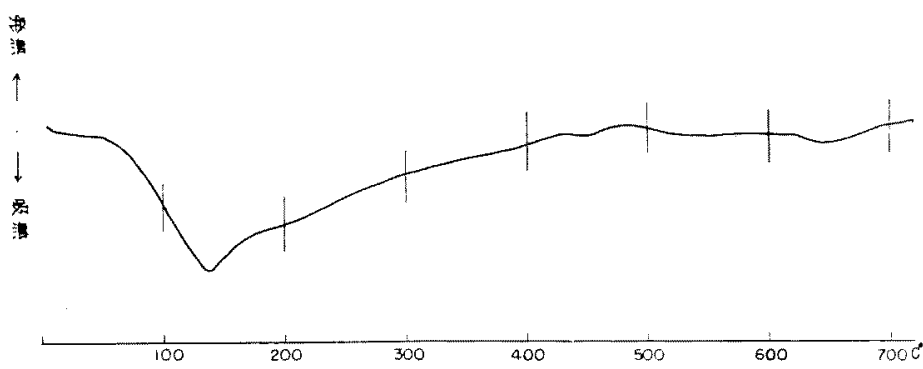

第 12 図発足ペントナイトの水籍㲘濁部の示差熱曲線 モンモリロナイト。 
第 4 表 発足ヘンントナイトの化学分析值

\begin{tabular}{|c|c|c|c|}
\hline & 1 & 2 & 3 \\
\hline $\begin{array}{l}\mathrm{SiO}_{2} \\
\mathrm{TiO}_{2} \\
\mathrm{Al}_{2} \mathrm{O}_{3} \\
\mathrm{Fe}_{2} \mathrm{O}_{3} \\
\mathrm{FeO} \\
\mathrm{CaO} \\
\mathrm{MgO} \\
\mathrm{MnO} \\
\mathrm{K}_{2} \mathrm{O} \\
\mathrm{Na}_{2} \mathrm{O} \\
\mathrm{CO}_{2} \\
\mathrm{H}_{2} \mathrm{O} \quad(+) \\
\mathrm{H}_{2} \mathrm{O}(-) \\
\mathrm{Ig} \text {. Loss }\end{array}$ & $\begin{array}{c}70.98 \text { wt } \% \\
10.68 \\
1.00 \\
0.92 \\
0.95\end{array}$ & $\begin{array}{r}71.42 \text { wt } 96 \\
10.93 \\
0.92 \\
0.98 \\
1.62\end{array}$ & $\begin{array}{r}67.52 \text { wt } \% \\
0.09 \\
12.62 \\
2.23 \\
0.08 \\
1.79 \\
0.59 \\
0.02 \\
0.23 \\
0.24 \\
0.32 \\
3.2 \\
6.9\end{array}$ \\
\hline
\end{tabular}

1：北海道工業試臨場分析（浦島，1963）。

2 : 同上。

3：PHd1 水笺沈澱部。住友金属銥山株式会社分析。

Sand, 1960) に近似している。

この表の 1 と 2 によると, 発足ベントナイトの $\mathrm{SiO}_{2} / \mathrm{Al}_{2} \mathrm{O}_{3}$ は 6.5 と 6.6 になり， ヘントナイトとしては，やや大きい值を示し，酸性白土に近い（加藤，1961；内田， 1946)。これは分析した鉱石中に原岩の石英が多くふくまれていることによると推定され

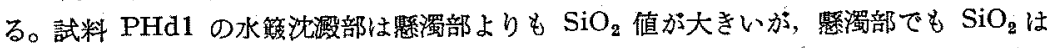
59.86\% であつて，モンモリロナイトのほかに $\alpha$ クリストバル石がふくまれていること を示す X 線回折結果と一致している。

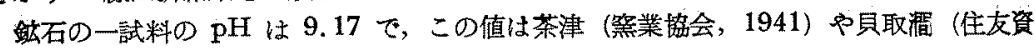
料)のヘントナィトの場合と大差がない。

\section{g. 塩基交換容量}

発足ヘントナイト鉣石の 1 試料の塩基交換容量は $90.5 \mathrm{me} / 100 \mathrm{~g}$ で，その交換性塩基 はCa12 5me, Mg2.3me である（北海道炭礦汽船株式会社石宸化学研究所における測 定)。ベントナイトの篮基交換容量は，たいてい 50〜70me 壁度でるので，発足ベン トナイトが示すこの值はとくに高い。さきに，沸石の混在がヘンントナイトの性䁈に影響す ることを予想した（浦島，1963）が，この值はその点を裹づけるものである。

かりに，塩基交換容鋰が沸石によるものと限定すると，沸石の含有量は 15〜20\%と

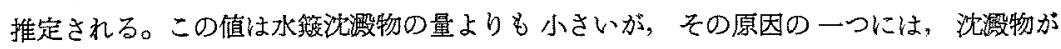
aークリストバル石・石英・斜長石などをふくんでいることがあげられる。

\section{6. 要 約}

発足ヘンントナイト铈床付近の茶津緑色凝灰岩層（中新層）は，进石の種類によつて，下 位名ら順に方沸石带 (A 带)・無沸石带 (N 需) ・斜プチロル沸石带 (C 带)に分けられ る。初生の N 置のほかに風化部で进石をふくまない場合がある。鉱床は N 带を下盤と し，C带中に罘胎し，レンズ状形態をむつものと推定される。 
上記の分帯は，発足ベントナイト鉣床付近では，層理とわずかに斜交し，西〜北西方の 茶津〜茅沼ベントナイト鎮枺付近まで追跡すると，地層区分と必ずしも一致しない。彷来 の報告では，沸石の分带が地層区分と一致する例が多いので，この点は注目される。

鉣石の原岩は流紋岩筫ガラス筫凝灰岩で，鉱石の鉱物組成は，モンモリロナイト・斜フ

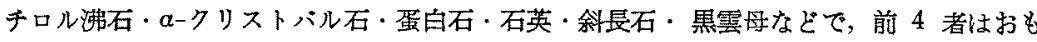
に火山ガラスから生成されたものである。ベントナイト化していない岩石には，とさに， 蛋白石化岩や石英化岩があり，石英化岩の一部には，氷長石が生じている。後者はべント ナイト鉱床の母岩には例の少ないものである。

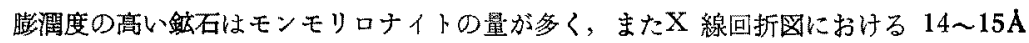
の形が複雑な場合であるという傾向がみとめられる。鉝石は必ず沸石をふくんでいるが，

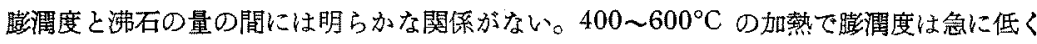
なる。鉱石の㙁基交換容量は約 $90 \mathrm{me} / 100 \mathrm{~g}$ である。

C 带の沸石は，X 線回折では，斜プチロル沸石であるが，熱と酸に詨する性筫には疑 問の点があるので，なお检討を要する。A 带の沸石㤬晶洞性の方沸石のX 線回折の結果 に一致しているが，東北地方の凝灰岩中の方沸石とはわずかにことなつている。

この地域周辺部の熱水金属鉱床の存在・沸石による分带の分布・発足ヘントナイト鉣床

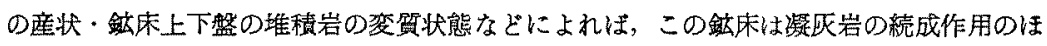
かに，熱水作用が加わつて生成したものと考えられる。

\section{引用 女 献}

Ames, L. L., Jr., Sand, L. B. and Goldich, S. S. (1958), A contribution on the Hector, California bentonite deposits. Econ. Geol., 53,22 37.

地質調查所 (1954)，日本凃産誌，IV.

Coombs, D.S. (1954), The nature and alteration of some Triassic sediments from Southland, New Zealand. Trans. Roy. Soc. N. Z., 82, 65 109. (1955), X-ray observations on wairakite and non-cubic analcime. Mineral. Mag., 30,699 708. Ellis, A. J., Fyfe, W. S. and Talor, A. M. (1959), The zeolite facies, with comments on the interpretation of hydrothermal syntheses. Geochim. Cosmochim. Acta., 17, 53 107.

Deffeyfs, K.S. (1959), Zeolite in sedimentary rocks. Jour. Sed. Pet., 29, 602 $\sim 609$.

古館争治（1936），檜山支庁管内，奥尼島全域. 北海道有用磺産物調查，7，121１82.

Hayashi, H, and Sudo, T. (1957), Zeolite-bearing bentonite. Miner. Jour., $2,196 \sim 199$.

林 久人・須藤俊男・松网正近 (1960)，凝灰岩の粘土鉣物化々沸石化. 粘土科学の進歩， $2,157 \sim 164$.

北海道商工部資源課 (1960)，道西地域鉱業開発振興計画調查報告書. 1 115. 本多䩗郎 (1960)，モンモりロナイト一沸石共生の一例. 枮土科学の進歩，2，136〜145. Iijima. A. (1961), Diageneitc alteration of some acidic tuffs in the Kushiro 
coal basin. Japanese Jour. Geol. Geogr., 32,507 522.

石橋正夫・浦岛幸世・笹木 敏 (1960)，堀株川支流発足山地の鉱床調查概報. 栍丹半岛 地域調査報告, $1 \sim 26$.

加藤忠蔵（1961），酸性白土とペントナイトの工業利用. 粘土科学， 1,40〜47.

木崎喜焳 (1960), 群馬罢碓永産のベントナイト. 粘土科学の進歩, 2, 146〜156.

(1963), 群馬景南部第三紀層中の沸石の産状. 粘土科学, 3,228〜238.

久保恭輔 (1954)，茅沼炭田の地質. 地調月報， 5,315 326.

Mason, B. and Sand, L. B. (1960), Clinoptilolite from Patagonia; the relationship between clinoptilolite and heulandite. Amer. Miner., 45, 341 350.

McConnell, D. (1952), Viséite, a zeolite with the analcime structure and containing linked $\mathrm{SiO}_{4}, \mathrm{PO}_{4}$ and $\mathrm{H}_{2} \mathrm{O}_{4}$ groups. Amer. Miner., 37, 609 621.

Mumpton, F. A. (1960), Clinoptilolite refined. Amer. Miner., 45, 351 369.

大森啓一・関 寿和・坂本 光 (1961)，山形県上山産ベントナイトのX 線的性質. 岩鉱. $45,82 \sim 88$.

Packham, C.H. and Crook, K. A. W. (1960), The principle of diagenetic facies and some of its implications. Jour. Geol., 68,392 407.

Ross, C. S. (1941), Sedimetary analcite. Amer. Miner., 26,627 629 .

斎藤 化 $(1960)$, 非金属資源. 北海道の地下資源，61７5.

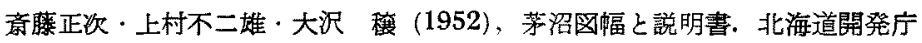

下斗来俊夫 ·古館兼治 (1936)，檜山支庁管内，爾志郡・久遠郡・太櫓郡全域およひ瀨相 郡一部. 北海道有用磺産物調查, $7,45 \sim 120$.

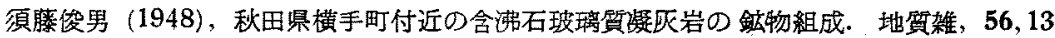
$\sim 16$.

Sudo, T., Nishiyama, T. Chin, K. and Hayashi, H. (1963), Mordenite and clinoptilolite in glassy tuffs of Japan. Jour. Geol. Soc. Japan, 69, 1 14.

Suzuki, J. (1961), Clinoptilolite in the Miocene tuffs and thermal properties of them from the Chita Peninsula, Aichi Prefecture. Bull. Aichi Gakugei Univ., 10, 137 150 .

鈴木好一・北崎梅香 (1954)，茅沼炭田における宸質变化について（その2）夾炭層の粘 土について. 翼源研最報, 33, 125 137.

内田宗義 (1946), 能渭土. 北隆館.

浦島幸世 (1963)，発足ベントナイトの鉱物組成。北海道鉱山学会誌，19，42４5，

- ·庄谷幸夫・須崎祐吉 (1963)，北海道発足ベントナイト鉱床。粘土科学討論会 講演.

·庄谷幸夫・須崎祐吉 (1964), 北海道発足ベントナイト鉃床（第 2 報）(要旨)。 日剑読. 80,742 743.

渡辺武彦・小野宗三郎 (1959)，ベントナイトの病資的研究. 粘土科学の進歩，1，378〜 387.

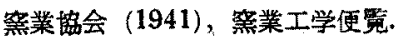

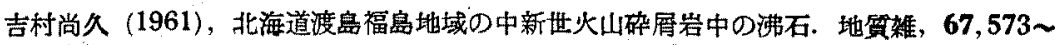
583 . 